\title{
Evaluation of MRR after WEDM Depending on the Resulting Surface
}

Katerina Mouralova, Josef Bednar, Jiri Kovar, Jindrich Mach

Faculty of Mechanical Engineering, Brno University of Technology. Technicka 2896/2, 61669 Brno. Czech Republic. E-mail: mouralova@fme.vutbr.cz, bednar@fme.vutbr.cz,kovar@fme.vutbr.cz,mach@fme.vutbr.cz

The aim of this article is to evaluate the material removal rate (MRR) after wire electrical discharge machining (WEDM) and subsequent characteristics of the machined surface. For efficient processing, the aim is to achieve the highest MRR values but with regard to the preserving of required quality and functional characteristics of the surface. During the electrical discharge of material removal craters occur on the workpiece surface and due to diffusion process here premixed and melted material of fodder and wire electrodes cling. As a result of melting and fast cooling down of the workpiece material microcracks may occur on its surface.

Keywords: WEDM, Electrical Discharge Machining, Design of Experiment, SEM, Aluminium alloy

\section{Acknowledgement}

This work is an output of research and scientific activities of NETME Centre, supported through project NETME CENTRE PLUS (LO1202) by financial means from the Ministry of Education, Youth and Sports under the „National Sustainability Programme I“.

This part of work was carried out with the support of core facilities of CEITEC-Central European Institute of Technology under CEITEC - open access project, ID number LM2011020, funded by Ministry of Education, Youth and Sports of the Czech Republic under the activity Projects of major infrastructures for research, development and innovations.

\section{References}

[1] ABBAS, N. M., SOLOMON, D. G., \& BAHARI, M. F. (2007). A review on current research trends in electrical discharge machining (EDM). In: International Journal of machine tools and Manufacture, pp. 1214-1228.

[2] HO, K. H., NEWMAN, S. T., RAHIMIFARD, S., \& ALLEN, R. D. (2004). State of the art in wire electrical discharge machining (WEDM). In: International Journal of Machine Tools and Manufacture, pp. 1247-1259.

[3] HO, K. H., \& NEWMAN, S. T. (2003). State of the art electrical discharge machining (EDM). In: International Journal of Machine Tools and Manufacture, pp. 1287-1300.

[4] OSIČKA, K., FIŠEROVÁ, Z., OTOUPALÍK, J. (2015). Influence of cutting tool overhangs at machining of hardened steels. In: Manufacturing TECHNOLOGY, pp. 188-191.

[5] MIČIETOVÁ, A., NESLUŠAN, M., ČILLIKOVÁ, M. (2013). Influence of surface geometry and structure after non-conventional methods of parting on the following milling operations. In: Manufacturing TECHNOLOGY, pp. 199-204.

[6] MAŇKOVÁ, I., VRABEC, M., KOVAC, P. (2013). Artificial Neural Network Application for Surface Roughness Prediction when Drilling Nickel Based Alloy. In: Manufacturing TECHNOLOGY, pp. 193-199.

[7] AHMAD, R. N., DERMAN, M. N., \& MARZUKI, M. (2010). Primary study on machiability of aluminium matrix composite using WEDM. In: International Journal of Engineering \& Technology, pp. 145-150.

[8] PRAKASH, J. U., MOORTHY, T. V., \& PETER, J. M. (2013). Experimental Investigations on Machinability of Aluminium Alloy (A413)/Flyash/B 4 C Hybrid Composites using Wire EDM. Procedia Engineering, pp. 13441353.

[9] SOMASHEKHAR, K. P., RAMACHANDRAN, N., \& MATHEW, J. (2010). Material removal characteristics of microslot (kerf) geometry in $\mu$-WEDM on aluminum. In: The International Journal of Advanced Manufacturing Technology, 51(5-8), pp. 611-626.

[10]STASTNY, J., \& SKORPIL, V. (2007). Analysis of algorithms for radial basis function neural network. In: Personal Wireless Communications, Springer US, pp. 54-62.

[11]STASTNY, J., \& SKORPIL, V. (2007). Genetic algorithm and neural network. In: Proceedings of the 7th WSEAS International Conference on Applied Informatics and Communications, pp. 347-351.

[12] GULINA, I., MATOUŠEK, R. (2014) The RRT algorithms and a spatial index. In: 20th International Conference on Soft Computing, MENDEL 2014, pp. 279-284.

[13]ABBADI, A., MATOUŠEK, R. (2012). RRTs Review and Statistical Analysis. In: International Journal of Mathematics and Computers in Simulation, pp. 1-8. 